\title{
Allergic reaction and metal hypersensitivity after shoulder joint replacement
}

\author{
A. Pautasso $^{1}$ (D) $\cdot$ I. Zorzolo $^{1} \cdot$ E. Bellato ${ }^{2} \cdot$ P. Pellegrino $^{3} \cdot$ A. Ferrario $^{4} \cdot$ E. Pira $^{1,4} \cdot$ F. Castoldi $^{1,2}$
}

Received: 3 November 2020 / Accepted: 17 September 2021 / Published online: 1 November 2021

(c) The Author(s) 2021

\begin{abstract}
Purpose Metal ion release may cause local and systemic effects and induce hypersensitivity reactions. The aim of our study is first to determine if implant-related hypersensitivity correlates to patient symptoms or not; second, to assess the rate of hypersensitivity and allergies in shoulder arthroplasty.

Methods Forty patients with shoulder replacements performed between 2015 and 2017 were studied with minimum 2-year follow-up; no patient had prior metal implants. Each patient underwent radiographic and clinical evaluation using the Constant-Murley Score (CMS), 22 metal and cement haptens patch testing, serum and urine tests to evaluate 12 metals concentration, and a personal occupational medicine interview.

Results At follow-up (average $45 \pm 10.7$ months), the mean CMS was $76 \pm 15.9$; no clinical complications or radiographic signs of loosening were detected; two nickel sulfate (5\%), 1 benzoyl peroxide (2.5\%) and 1 potassium dichromate $(2.5 \%)$ positive findings were found, but all these patients were asymptomatic. There was an increase in serum aluminum, urinary aluminum and urinary chromium levels of 1.74, 3.40 and 1.83 times the baseline, respectively. No significant difference in metal ion concentrations were found when patients were stratified according to gender, date of surgery, type of surgery, and type of implant.

Conclusions Shoulder arthroplasty is a source of metal ion release and might act as a sensitizing exposure. However, patch test positivity does not seem to correlate to hypersensitivity cutaneous manifestations or poor clinical results. Laboratory data showed small constant ion release over time, regardless of gender, type of shoulder replacement and implant used.
\end{abstract}

Levels of evidence Level II.

Keywords Patch test $\cdot$ Allergies $\cdot$ Metal hypersensitivity $\cdot$ Shoulder arthroplasty $\cdot$ Cement

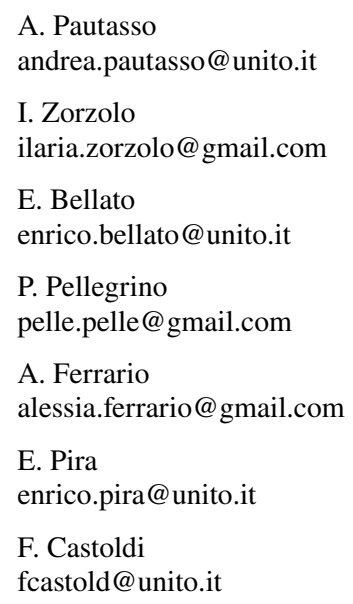

1 University of Turin, Via Gianfranco Zuretti 29, 10126 Turin, Italy

2 Orthopaedic and Traumatology Department, San Luigi Gonzaga Hospital, University of Turin, Regione Gonzole 10, 10043 Orbassano, Italy

3 Oncologic Orthopaedic Department, Orthopaedic and Trauma Center - Città della Salute e della Scienza, University of Turin, Via Gianfranco Zuretti 29, 10126 Turin, Italy

4 Occupational Medicine Division, Department of Public Health and Pediatric Sciences, Orthopaedic and Trauma Center - Città della Salute e della Scienza, University of Turin, Via Gianfranco Zuretti 29, 10126 Turin, Italy 


\section{Introduction}

Contact dermatitis is a common disease affecting up to $20 \%$ of the general population. Metals represent the most common allergens. In particular, nickel (Ni) sensitivity has been reported to have a prevalence of $11.4 \%$, followed by cobalt (Co) at $2.7 \%$ and chromium $(\mathrm{Cr})$ at $1.8 \%$ [1]. Other metals known to cause allergies are beryllium (Be), tantalum (Ta), titanium (Ti) and vanadium (V) [2-4]. All these metals are used for the production of orthopedic implants $[5,6]$. Moreover, components of the bone cement such as polymethyl methacrylate (PMMA), benzoyl peroxide (BPO), N,N-dimethyl-p-toluidine, and hydroquinone [7] have been implicated as relevant allergens.

Allergy complications subsequent to the use of orthopedic implants encompass both skin reactions (e.g., local $[4,8,9]$ and systemic eczema [4, 7-10], urticaria [9, 11], sterile fistulas [12]) and non-cutaneous manifestations, both systemic (e.g., chronic fatigue syndrome, fibromyalgia and autoimmune/inflammatory syndrome [13]) and local (pain, joint effusion and reduced range of motion [7, 9, 14]).

The role of immunologic reactions in implant failure has not been fully understood. In addition, the effect of pre-existing metal allergies resulting in implant failure and the role of metal released by the implant on secondary sensitization are unknown [5].

All implants undergo corrosion inside the human body by various mechanisms [6], and elevated concentrations of metal ions have been measured in capsular and periprosthetic tissues [15, 16], blood [15, 17], urine [17], and in distant organs including liver, spleen, and lymph nodes [18].

Most of the literature on metal hypersensitivity is focused on total hip (THA) $[15,19,20]$ and total knee arthroplasty (TKA) $[4,21]$, due to their widespread implantation and, partially, due to the high complication rate of the first generation of metal-on-metal hip coupling $[2,16,17]$.

Shoulder arthroplasty is also prone to corrosion, as demonstrated by the increase in metal ions in blood [22] and urine [23] after surgery. Implant retrieval studies show that tribocorrosion, a combination of fretting and corrosion marks, can occur at taper junctions of modular components of shoulder prosthesis[24-26]. Moreover, many taper junctions connect components made of different metal alloys, resulting in the implant being subjected to galvanic corrosion [27]. Additionally, metal debris can be released from unexpected metal-on-metal contacts, such as in chronic implant instability [28] or in the case of retained metal glenoid anchor emerged at the joint line [29].

Despite its constant incidence increase in the past decade [30], there is a paucity of evidence on the effect of metal and bone cement hypersensitivity in shoulder arthroplasty.
To our knowledge, few studies have been published on this subject [9, 31-33].

The aim of our study is: first, to determine if implant related hypersensitivity correlates to patient symptoms or not; second, to assess the prevalence of implant hypersensitivity and the allergens that may trigger the reaction in shoulder arthroplasty.

\section{Materials and methods}

A retrospective monocentric study was conducted with prospective data collection. In light of the Italian law, no institutional review board approval was mandatory for this study. The study has been performed in accordance with the ethical standards of the 1964 Declaration of Helsinki and has been carried out in accordance with relevant regulations of the Italian National Health Care System. Informed consent was obtained from all patients.

One hundred and sixteen primary shoulder arthroplasties were performed at CTO Hospital - Città della Salute e della Scienza - Turin, Italy between January 2015 and December 2017. The inclusion criteria were glenohumeral osteoarthritis (either concentric or cuff tear arthropathy) and proximal humeral fractures treated with shoulder arthroplasty with a minimum follow-up of 2 years. Exclusion criteria were: the presence or the history of other implants besides the shoulder replacement (e.g., other orthopedic devices, cardiac and dental implants, etc.), immunological disorders or immunotherapy, megaprosthesis, and pregnancy.

All the patients included in the study underwent a radiographic and clinical evaluation performed by the same orthopedic surgeon [AP] at follow-up. Clinical shoulder function was assessed with the Constant-Murley Score (CMS) [34], and $\mathrm{x}$-rays were reviewed to rule out any sign of loosening and incongruity of the prosthetic components.

An occupational medicine evaluation was conducted along with a questionnaire about hypersensitivity and environmental exposure to sensitizing compounds. Serum, urine tests and a patch test for metal ions were performed. Serum and urine samples were analyzed by inductively coupled plasma mass spectrometry (ICP-MS). The obtained data were compared with the maximum reference values according to the Italian Society Reference Values (SIVR) [35] and Italian Higher Institute of Health's report [36]. The haptens used in the patch test and their concentration, and the metals tested in the serum and urine samples are reported in Table 1. The patients' skin was checked for reactions by the same senior occupational physician $[\mathrm{AF}]$ at 48 and $72 \mathrm{~h}$ after the patch test application. Results were recorded according to the Italian Society of Environment and Occupational Allergological Dermatology (SIDAPA) criteria [37]. 
Table 1 Metal and cement components tested with the patch test

\begin{tabular}{|c|c|c|c|c|c|c|c|}
\hline \# & Metals tested & Concen-tration & ID & $\#$ & Substances tested & Concen-tration & ID \\
\hline 1 & Aluminum Hydroxide $*$ & $10 \%$ & 99,994 & 17 & (2-Hydroxyethyl) Methacrylate & $1 \%$ & E2477 \\
\hline 2 & Ammonium Molybdate & $1 \%$ & $2401 X$ & 18 & Benzoyl Peroxide & $1 \%$ & E0201 \\
\hline 3 & Cadmium Sulfate * & $2 \%$ & $2307 X$ & 19 & Ethyleneglycol Dimethacrylate & $2 \%$ & E1850 \\
\hline 4 & Cobalt Chloride * & $1 \%$ & E002 & 20 & Hydroquinone & $1 \%$ & E0800 \\
\hline 5 & Cobalt (II) Sulfate & $1 \%$ & $0615 X$ & 21 & Methyl Methacrylate & $2 \%$ & E1800 \\
\hline 6 & Chromium (III) Chloride * & $2.5 \%$ & $2412 X$ & 22 & Triethyleneglycol Methacrylate & $2 \%$ & E1851 \\
\hline 7 & Chromium Sulfate & $0.2 \%$ & $1833 X$ & & & & \\
\hline 8 & Iron Chloride * & $2 \%$ & 2406 & & & & \\
\hline 9 & Iron Sulfate & $2 \%$ & 2405 & & & & \\
\hline 10 & Manganese Bi-oxide * & $10 \%$ & 99,997 & & & & \\
\hline 11 & Nickel Sulfate * & $5 \%$ & E0003 & & & & \\
\hline 12 & Potassium Dichromate & $0.5 \%$ & E0001 & & & & \\
\hline 13 & Tantalum * & $1 \%$ & $2311 X$ & & & & \\
\hline 14 & Titanium (IV) Oxide * & $0.1 \%$ & $2419 X$ & & & & \\
\hline 15 & Vanadium Chloride * & $0.2 \%$ & $2449 X$ & & & & \\
\hline 16 & Zirconium (IV) Sulfate * & $2.5 \%$ & $1019 X$ & & & & \\
\hline
\end{tabular}

*: Serum and urine metal concentrations analyzed with ICP-MS; ID: International product identification

Statistical analysis was performed using IBM SPSS ${ }^{\circledR}$ (Data Analysis and Statistical Software). The Kolmogorov-Smirnov test of normality was used to study the values distributions of all data series obtained from CMS and ion concentrations analysis. All series had a non-normal distribution; as a consequence, nonparametric tests such as the Mann-Whitney U test and the Kruskal-Wallis test were used to compare the different subgroups of patients' values (stratification of the samples by gender, surgical date, type of arthroplasty performed, and implant used). $\mathrm{P}$ values of $<0.05$ were considered to be significant.

\section{Results}

Forty-nine patients were eligible to be included, but only 40 patients agreed to be enrolled in our study. The mean age was $69 \pm 7$ years old (53-78), 27 (67.5\%) patients were female and $13(32.5 \%)$ were male. Patients' characteristics stratified by diagnosis, type of arthroplasty performed, surgical date, occupational status, history of hypersensitivity, implant used and its metal composition are reported in Table 2 and Table 3. The mean follow-up was $45 \pm 10.7$ months (27-60).

The mean CMS recorded at follow-up was $76 \pm 15.9$ (43-97). In the proximal humeral fracture group the mean CMS was $75 \pm 16.2$ (43-97), while in the osteoarthritis group the CMS was $77 \pm 15.8(47-97)(p=0.69)$. None of the patients reported either local or systemic skin reactions, pruritus, joint effusion or prolonged joint pain at rest. No radiographic signs of loosening or other complications were detected at final follow-up.
The occupational medicine questionnaire highlighted eventual sensitizing environmental exposure in 17 patients. Eight patients were industrial factory employees with potential for contact with allergenic substances (e.g. paints, solvents, vegetables, mineral and industrial oils, resins); in particular 3 of these were metalworkers. Out of the 32 patients who worked in the service sector, 4 reported contacts with metal substances and 5 further patients reported possible contacts with other allergenic materials in their professional activity.

In $16(40 \%)$ patients allergic symptoms were detected, either formally diagnosed or self-reported. Four of these patients reported intolerance, without prior investigation, to costume jewelry, with the appearance of erythema in the contact area even before shoulder replacement was performed.

Patch tests were positive in 4 patients (10\%). Three cases were mildly positive: 1 patient $(2.5 \%)$ to nickel, $1(2.5 \%)$ to BPO and $1(2.5 \%)$ to potassium dichromate. Another 1 case $(2.5 \%)$ was found strongly positive to nickel (patch-test results are summarized in Table 4). The 2 cases of nickel hypersensitivity were among the ones who reported dermal reactions to costume jewelry. The patient mildly positive to BPO underwent a cemented shoulder replacement. Despite the patch test positivity, these 4 patients did not show any clinical or radiographic signs of shoulder implant complications (Patients 9, 13, 24 and 28 in Appendix 1).

Serum metal ion ICP-MS analysis showed an increase in aluminum concentration with a mean value of $10.43 \pm 3.45 \mu \mathrm{g} / \mathrm{L}$ (4.80-21.30; Reference Maximum Values [RMV]: 6.00), which is 1.74 times the baseline. The other 
Table 2 Demographic sample description

\begin{tabular}{|c|c|c|}
\hline Characteristics & No. Patients & $\%$ \\
\hline \multicolumn{3}{|l|}{ Preoperative diagnosis } \\
\hline Proximal humeral fracture & 26 & $65.0 \%$ \\
\hline Gleno-humeral osteoarthritis & 14 & $35.0 \%$ \\
\hline \multicolumn{3}{|l|}{ Type of replacement } \\
\hline Partial (Hemiarthroplasty) & 15 & $37.5 \%$ \\
\hline Total (Revers Shoulder Arthroplasty) & 25 & $62.5 \%$ \\
\hline \multicolumn{3}{|l|}{ Type of shoulder prosthesis } \\
\hline Bigliani/Flatow® - Zimmer Biomet $\bigodot$ & 13 & $32.5 \%$ \\
\hline Tornier Aequalis ${ }^{\mathrm{TM}} \mathrm{FX}$ - Wright Medical Group@ & 11 & $27.5 \%$ \\
\hline Tornier Aequalis ${ }^{\mathrm{TM}}$ Reversed II - Wright Medical Group $\odot$ & 16 & $40.0 \%$ \\
\hline Cemented implants (out of all arthroplasty) & 19 & $47.5 \%$ \\
\hline \multicolumn{3}{|l|}{ Year of surgery } \\
\hline 2015 & 17 & $42.5 \%$ \\
\hline 2016 & 12 & $30.0 \%$ \\
\hline 2017 & 11 & $27.5 \%$ \\
\hline \multicolumn{3}{|l|}{ Employment } \\
\hline Active & 9 & $22.5 \%$ \\
\hline Retired & 31 & $77.5 \%$ \\
\hline \multicolumn{3}{|l|}{ Current/Previous sector business } \\
\hline Industry & 8 & $20.0 \%$ \\
\hline Service & 32 & $80.0 \%$ \\
\hline Patients with allergic or suspected symptoms & 16 & $40.0 \%$ \\
\hline Skin Manifestation (out of all patients investigated) & 13 & $32.5 \%$ \\
\hline
\end{tabular}

Table 3 Prosthetic metallic components

\begin{tabular}{|c|c|c|c|c|c|c|c|}
\hline Implant & & Humeral stem & Humeral head & Humeral bearing & Glenosphere & Baseplate & Screws \\
\hline $\begin{array}{l}\text { Bigliani/Fla- } \\
\text { tow®_ Zimmer } \\
\text { Biomet@ }\end{array}$ & $\begin{array}{l}\text { Cemented } \\
\text { or not }\end{array}$ & $\begin{array}{l}\text { Ti-6Al-4 V+Ta } \\
\text { coated }\end{array}$ & I & UHMWPE & Cr-Co-Mo alloy & $\begin{array}{l}\text { Ti-6Al-4 V+Ta } \\
\text { coated }\end{array}$ & Ti-6Al-4 V \\
\hline $\begin{array}{l}\text { Tornier Aequa- } \\
\text { lis }{ }^{\mathrm{TM}} \text { Reversed II } \\
\text { - Wright Medi- } \\
\text { cal Group@ }\end{array}$ & Cemented & Cr-Co alloy & / & UHMWPE & Cr-Co alloy & $\begin{array}{l}\text { Ti-6Al-4 V + HA } \\
\text { coated }\end{array}$ & Ti-6Al-4 V \\
\hline $\begin{array}{l}\text { Tornier Aequa- } \\
\text { lis }{ }^{\mathrm{TM}} \text { Reversed II } \\
\text { - Wright Medi- } \\
\text { cal Group@ }\end{array}$ & Not Cemented & Ti-6Al-4 V & / & UHMWPE & Cr-Co alloy & $\begin{array}{l}\text { Ti-6Al-4 V+HA } \\
\text { coated }\end{array}$ & Ti-6Al-4 V \\
\hline $\begin{array}{l}\text { Tornier Aequa- } \\
\text { lis }{ }^{\mathrm{TM}} \text { FX - } \\
\text { Wright Medical } \\
\text { Group@ }\end{array}$ & Cemented or not & $\begin{array}{l}\text { Ti-6Al-4 V+HA } \\
\text { coated }\end{array}$ & Cr-Co alloy & I & I & / & I \\
\hline
\end{tabular}

Ti: Titanium; Al: Aluminum; V: Vanadium; Ta: Tantalum; Cr: Chromium; Co: Cobalt; Mo: Molybdenum; UHMWPE: Ultra-High-MolecularWeight Polyethylene; HA: Hydroxyapatite

serum metal ion concentrations were in range of normality (Fig. 1a, Table 5). Regarding the urinary metal ion ICP-MS analysis, a 3.40-fold and a 1.83-fold increase over aluminum and chromium RMV were observed, respectively (urinary aluminum mean value $20.38 \pm 12.52 \mu \mathrm{g} / \mathrm{L}$ [5.84-61.20;
RMV: 6.00]; urinary chromium mean value $0.64 \pm 0.30 \mu \mathrm{g} / \mathrm{L}$ [0.18-1.70; RMV: 0.35]) (Fig. 1b, Table 5).

No significant difference in serum nor urine metal ion concentrations was found when patients were stratified according to gender $(p \geq 0.17)$, year of surgery $(p \geq 0.14)$, type of surgery (Hemiarthroplasty vs Reverse Shoulder 
Table 4 Prosthetic metallic components

\begin{tabular}{llllll}
\hline Haptens tested & $\begin{array}{l}\text { Positive reac- } \\
\text { tions }(\%)\end{array}$ & \multicolumn{2}{l}{ Patch test reading $(\%)$} & \\
\cline { 2 - 6 } & & +++ & ++ & + & \pm \\
\hline (2-Hydroxyethyl) Methacrylate & 0 & 0 & 0 & 0 & 0 \\
Aluminum Hydroxide & 0 & 0 & 0 & 0 & 0 \\
Ammonium Molybdate & 0 & 0 & 0 & 0 & 0 \\
Benzoyl Peroxide & $1(2.5 \%)$ & 0 & 0 & $1(2.5 \%)$ & 0 \\
Cadmium Sulfate & 0 & 0 & 0 & 0 & 0 \\
Cobalt Chloride & 0 & 0 & 0 & 0 & 0 \\
Cobalt (II) Sulfate & 0 & 0 & 0 & 0 & 0 \\
Chromium (III) Chloride & 0 & 0 & 0 & 0 & 0 \\
Chromium Sulfate & 0 & 0 & 0 & 0 & 0 \\
Ethyleneglycol Dimethacrylate & 0 & 0 & 0 & 0 & 0 \\
Iron Chloride & 0 & 0 & 0 & 0 & 0 \\
Iron Sulfate & 0 & 0 & 0 & 0 & 0 \\
Hydroquinone & 0 & 0 & 0 & 0 & 0 \\
Manganese Bi-oxide & 0 & 0 & 0 & 0 & 0 \\
Methyl Methacrylate & 0 & 0 & 0 & 0 & 0 \\
Nickel Sulfate & $2(5 \%)$ & $1(2.5 \%)$ & 0 & $1(2.5 \%)$ & 0 \\
Potassium Dichromate & $1(2.5 \%)$ & 0 & 0 & $1(2.5 \%)$ & 0 \\
Tantalum & 0 & 0 & 0 & 0 & 0 \\
Titanium (IV) Oxide & 0 & 0 & 0 & 0 & 0 \\
Triethyleneglycol Methacrylate & 0 & 0 & 0 & 0 & 0 \\
Vanadium Chloride & 0 & 0 & 0 & 0 & 0 \\
Zirconium (IV) Sulfate & 0 & 0 & 0 & 0 \\
\hline & & 0 & 0 & 0 \\
\hline
\end{tabular}

\pm : Slight erythema; + : Uniform erythema with edema, papules or slight vesicles possible; $++:$ Erythema, edema, evident papules and vesicles that can protrude from the patch application area; +++ : Erythema, edema, very evident papules and vesicles, sometimes confluent in bubbles [29]
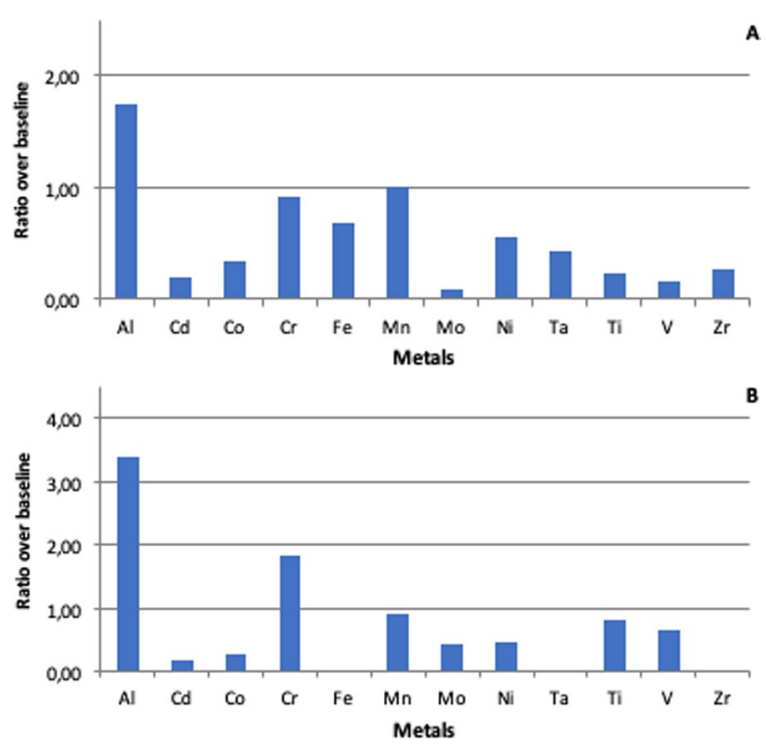

Fig. 1 Ratio between Observed Average Values (OAV) of each metal and its Reference Maximum Value (RMV) detected in serum (fig. A) and urine (fig. B). On the $y$-axis, the ratio expressed as a number over each metal baseline: a value over 1.00 is not physiological because over its maximum reference
Replacement) ( $\mathrm{p} \geq 0.31$ ), and type of implant (Bigliani/Flatow ${ }^{\circledR}-$ Zimmer Biomet $\odot$ vs Tornier Aequalis ${ }^{\mathrm{TM}} \mathrm{FX}-$ Wright Medical Group $\odot$ vs Tornier Aequalis ${ }^{\mathrm{TM}}$ Reversed II-Wright Medical Group $\odot)(\mathrm{p} \geq 0.14)$.

Patients' details of serum and urinary levels of metal ions are to be found in Appendix 2.

\section{Discussion}

The purpose of this study was, first, to evaluate whether allergies, diagnosed with a patch test, were related or not to patients' symptoms after shoulder arthroplasty; secondly, to determine the prevalence of implant-related hypersensitivity and the allergens that could trigger this reaction.

Hypersensitivity following shoulder arthroplasty is an underexplored subject in the literature. Only a few studies have focused on the possible allergic reactions to metals in patients who underwent shoulder replacement [32, 33]. Ko et al. [32] identified 6 patients with metal allergy after shoulder arthroplasty in a population of 1243 patients. Most of them had a routine early post-operative course; however, a progressive worsening in pain and range of motion, 
Table 5 Serum and urine laboratory results. Data expressed in $\mu \mathrm{g} / \mathrm{l}$, except iron (Fe) values expressed in $\mathrm{mg} / \mathrm{l}$

\begin{tabular}{|c|c|c|c|c|c|c|c|c|c|c|}
\hline \multicolumn{6}{|c|}{ Serum laboratory results } & \multicolumn{5}{|c|}{ Urine laboratory results } \\
\hline \multicolumn{2}{|c|}{ Average } & \multirow{2}{*}{$\frac{\mathrm{sSD}}{3.45}$} & \multirow{2}{*}{$\frac{\text { Min }}{4.80}$} & \multirow{2}{*}{$\frac{\operatorname{Max}}{21.30}$} & \multirow{2}{*}{$\frac{\text { RMV }}{6.00}$} & \multirow{2}{*}{$\begin{array}{l}\text { Average } \\
20.38\end{array}$} & \multirow{2}{*}{$\frac{\mathrm{sSD}}{12.52}$} & \multirow{2}{*}{$\frac{\text { Min }}{5.84}$} & \multirow{2}{*}{$\frac{\text { Max }}{61.20}$} & \multirow{2}{*}{$\frac{\text { RMV }}{6.00}$} \\
\hline $\mathrm{Al}$ & 10.43 & & & & & & & & & \\
\hline $\mathrm{Cd}$ & 0.30 & 0.17 & 0.10 & 1.20 & 1.50 & 0.26 & 0.43 & 0.00 & 2.60 & 1.50 \\
\hline Co & 0.34 & 0.27 & 0.18 & 1.85 & 1.00 & 0.43 & 0.48 & 0.01 & 1.80 & 1.50 \\
\hline $\mathrm{Cr}$ & 0.46 & 0.14 & 0.26 & 0.96 & 0.50 & 0.64 & 0.30 & 0.18 & 1.70 & 0.35 \\
\hline $\mathrm{Fe}$ & 444.85 & 58.77 & 303.00 & 508.00 & 646.49 & \multicolumn{4}{|c|}{ Not detected } & Not available \\
\hline $\mathrm{Mn}$ & 7.99 & 1.77 & 3.20 & 12.80 & 8.00 & 3.63 & 7.41 & 0.22 & 41.88 & 4.00 \\
\hline Mo & 0.41 & 0.74 & 0.10 & 4.60 & 5.00 & 42.32 & 33.36 & 4.01 & 172.21 & 100.00 \\
\hline $\mathrm{Ni}$ & 1.12 & 0.68 & 0.53 & 4.02 & 2.00 & 2.34 & 2.21 & 0.24 & 9.65 & 5.00 \\
\hline Тa & 0.14 & 0.10 & 0.00 & 0.32 & 0.32 & \multicolumn{4}{|c|}{ Not detected } & 0.28 \\
\hline $\mathrm{Ti}$ & 16.85 & 3.25 & 10.97 & 25.77 & 70.00 & 8.25 & 4.90 & 1.32 & 20.94 & 10.00 \\
\hline V & 0.03 & 0.03 & 0.00 & 0.18 & 0.20 & 0.65 & 0.30 & 0.16 & 1.36 & 1.00 \\
\hline $\mathrm{Zr}$ & 0.26 & 0.17 & 0.16 & 1.22 & 0.95 & \multicolumn{4}{|c|}{ Not detected } & 2.00 \\
\hline
\end{tabular}

sSD: sample Standard Deviation; Min: Minimum value; Max: Maximum value; RMV: Reference Maximum Value; Al: Aluminum; Cd: Cadmium; Co: Cobalt; Cr: Chromium; Fe: Iron; Mn: Manganese; Mo: Molybdenum; Ni: Nickel; Ta: Tantalum; Ti: Titanium; V: Vanadium; Zr: Zirconium without any cutaneous manifestation, appeared within the first 12 weeks. After infection was ruled out, patients were investigated for hypersensitivity: 3 resulted allergic to nickel, 1 to cobalt, 1 to chromium and 1 to multiple metals (Co, $\mathrm{Cr}, \mathrm{Mo}, \mathrm{Ti}$, and $\mathrm{Al}$ ). All the patients but the latter one (no hypoallergenic implant was available for him) underwent revision surgery and 4 reported improvement in symptoms. Kennon et al. [33] have recently retrospectively reported on 43 patients, with a total of 52 having undergone shoulder arthroplasty, who self-reported metal hypersensitivity. Patients referred allergies to nickel (37 cases), cobalt chrome (4 cases), copper ( 2 cases), gold ( 2 cases), titanium (1 case), zinc (1 case), and nonspecific metals ( 8 cases). Eight patients reported multiple metal allergies. A subset of 13 shoulders underwent skin patch testing, and only one resulted negative. Despite the high prevalence of nickel sensitivity reported in patients' past medical history before surgery, all patients received an implant containing this metal. Nevertheless, they reported a significant improvement in function and pain relief after surgery, without any difference between the group with a positive skin patch and the patients that only declared a metal hypersensitivity. There were 2 insidious glenoid loosenings, not attributable to hypersensitivity and no cutaneous reactions.

Additionally, non-metallic materials can play a role in allergic reactions in patients with shoulder replacement. Bircher et al. [9] reported on a patient with cemented total shoulder arthroplasty who developed chronic pain associated with an erythematous plaque on the upper arm characterized by lymphocytic infiltrate. After BPO hypersensitivity was diagnosed with skin patch testing, the patient underwent an uncemented revision procedure that led to the resolution of the symptoms.
In our study the rate of metal and bone cement hypersensitivity was $10 \%$ (4 patients). Nickel was the commonest allergen, as described in the general population[1]. The two patients that were sensitive to nickel received a reverse arthroplasty containing this metal in the glenosphere. Interestingly, both reported preoperative skin reactions to costume jewelry, and thus, the shoulder implant was not the sensitizing exposure. One patient with shoulder hemiarthroplasty characterized by a humeral head made of chromium proved to be hypersensitive to potassium dichromate and was found to have increased serum and urine levels of chromium. He was previously exposed to metals in his work; however, he never experienced skin hypersensitivity symptoms. The last skin patch was positive to BPO, a normally used initiator in bone cement [7]. This patient's medical history was negative for previous exposures and a cemented shoulder arthroplasty was performed, which could be the sensitizing factor. However, BPO is a well-known skin irritant, so a weak positivity, as occurred in this case, can be subsequent either to contact sensitization or just to irritation [38].

Although 4 patients had a positive patch test, they experienced neither skin reactions nor non-cutaneous manifestations connected to metal and bone cement hypersensitivity. At the latest follow-up, $\mathrm{x}$-rays showed no signs of failure and good results in terms of CMS (Patients 62, 81, 84 and 96 in Appendix 1) were observed.

Our metal ion ICP-MS analysis showed an increase in serum and urinary aluminum and urinary chromium. However, no significant correlation could be found, especially with hypersensitive and exposed subjects since we could identify only one.

Unlike Reiner et al.'s work [22], we could not find a difference in ion release between hemiarthroplasty and reverse 
shoulder arthroplasty. In their study, titanium blood concentration was significantly higher in the reverse shoulder arthroplasty group, possibly due to galvanic corrosion at the cobalt-chromium glenosphere and at the titanium alloy baseplate taper junction. Also, 4 titanium screws were used to secure the baseplate, which might have acted as an additional source for titanium ion release. The semiconstrained biomechanical concept of the reverse shoulder replacement design places high friction and shear forces at the glenosphere-baseplate and at the baseplate-screws-bone interfaces. Increased micro-motions might facilitate fretting and corrosion damage resulting in higher blood metal ion concentrations in these patients. Furthermore Reiner et al. [22] found significantly higher cobalt, chromium and titanium levels in total shoulder arthroplasty patients than in controls without any implant. A direct comparison with our study cannot be drawn since their measurements were taken on whole blood, resulting in lower values than ours [39].

Urinary metal ion concentrations have been reported by Khan et al. [23] to be increased in shoulder arthroplasty. They found an increase in excretion of cobalt, chromium, aluminum, titanium and molybdenum unlike the sole rise in chromium and aluminum we detected. However, their results were based on a single case report of a patient with shoulder metallosis.

Aluminum is a component of the titanium alloy; however, we found an isolated increase in aluminum with mean titanium concentration below the RMV. Studies that tested aluminum concentrations found no significant increase both in hip (both in metal-on-metal [40-42] and ceramic-on-ceramic coupling [41, 42]) and in knee replacement [43]. Chronic aluminum exposure has been implied in a specific encephalopathy with a dementia syndrome. Serum concentration of approximately $13 \mu \mathrm{g} / \mathrm{L}$ measured in occupationally-exposed workers correlates with a decline in neuropsychological tests; however, those subjects did not manifest encephalopathy at long-term follow-up [44]. The mean data we reported are below this threshold. The measurement of aluminum concentration is complicated by its environmental abundance and the small amount in serum, placing this analysis at high risk of contamination [45].

We did not find any difference in ion release over time when we stratified our patients according to the length of follow-up. In hip arthroplasty with metal-on-metal coupling, metal ion release is greater at a short follow-up resulting in higher cobalt and chromium whole blood or serum and urine concentrations [17, 40,46]. This phenomenon has been attributed to an accelerated wear rate that affects metal implants when they are subjected to the early load cycles; this elevated wear rate decreases over time with the running-in of the components [47]. The reduction in wear rate translates clinically to a significant reduction in cobalt and chromium concentrations in urine and whole blood or serum at a longer follow-up, despite remaining higher than control groups [17, 40]. Shoulder arthroplasty is subjected to accelerated running-in wear as well [48]; however, the typical metal-on-polyethylene coupling used in shoulder replacement might lead to a lower release of metal ions. It may be possible that we were not able to identify an ion concentration trend over time due to the lack of multiple measurements in the same patient.

\section{Limitations and strengths}

This study had several limitations. First, we could include only a small number of patients and this also affected patients' stratification process. Second, we did not have a control group without implants. Third, we did not have preoperative data on skin patch testing and on metal ion concentrations, despite data being collected prospectively. Fourth, we could not draw definitive conclusions about the causative link between shoulder arthroplasty and hypersensitivity since we had to rely on patients' past medical history for previous metal sensitizations and exposure. In the literature [49] there is no general consensus on the role of patch tests before surgery, due to its intrinsic allergenic potentiality and lack of long-term impact on implants survival (e.g., Bravo et al. [21] reported no difference in joint revision rates among patients who underwent knee arthroplasty with a positive or a negative preoperative patch test). Fifth, we were able to collect serum and urine samples during a single follow-up evaluation only; therefore, we cannot describe a precise trend of ion release over time. Sixth, we used skin patch tests, which represent the gold standard for contact dermatitis diagnosis, since they are easy to use, readily available and cheap. However, other in-vitro tests are available such as the Lymphocyte Transformation Test (LTT) that measures lymphocytes in peripheral blood after allergen exposure [49]. LTT is more appropriate for diagnosing metal hypersensitivity induced by deep implants and it is a better option for detecting systemic allergies, while patch test better identifies cutaneous hypersensitivity [50]. However, skin patch tests are cheaper, widely available, and have good reliability.

Despite these critical points, to our knowledge this is the first study that provides data on allergies and hypersensitivity of patients undergoing shoulder replacement. This study explores hypersensitivity, allergies to metals or bone cement components in patients with shoulder replacement using patch tests. Unlike prior studies in the literature that only investigated patients formally diagnosed or self-reported metal allergies undergoing shoulder replacement, this cohort of patients treated with shoulder arthroplasty were studied regardless of their immunological status before and after surgery.

Additionally, the time point for which patients underwent blood and urine metal ion tests was different from patient 
to patient (i.e., some were tested at 1 year, some at 2 years after surgery). Post-hoc analysis of this data allowed us to understand the rate of ion release in relation to the length of follow-up.

\section{Conclusions}

Shoulder arthroplasty is a possible source of metal ion release and, along with other substances such as BPO, are potential causes of hypersensitivity. In this study, the rate of patch test positivity was $10 \%$, but this does not correlate to cutaneous manifestations or poor clinical and radiographic results. Systemic ion release over time is a possible concern, in particular regarding aluminum and chromium, but no clinical effects were observed in our study group. Factors like gender, type of shoulder replacement and implant used did not play a role either in hypersensitivity or in systemic ion release for this study.

\section{Appendix 1}

\begin{tabular}{|c|c|c|c|c|c|c|c|c|}
\hline Id & Dos & Type of surgery & Type of Implant & $\begin{array}{l}\text { Cemented } \\
\text { Implant? }\end{array}$ & CMS & $\begin{array}{l}\text { Current/Pre- } \\
\text { vious sector } \\
\text { business }\end{array}$ & $\begin{array}{l}\text { Known Or } \\
\text { suspected } \\
\text { allergic symp- } \\
\text { toms }\end{array}$ & Patch test result \\
\hline 1 & Jan-15 & RSA & $\begin{array}{r}\text { Bigliani/Flatow® - } \\
\text { Zimmer Biomet } \odot\end{array}$ & No & 47 & Service & No & Negative \\
\hline 2 & Feb-15 & RSA & $\begin{array}{l}\text { Tornier Aequalis }^{\mathrm{TM}} \\
\text { Reversed II - } \\
\text { Wright Medical } \\
\text { Group@ }\end{array}$ & No & 97 & Service & No & Negative \\
\hline 3 & Mar-15 & RSA & $\begin{array}{l}\text { Tornier Aequalis }^{\mathrm{TM}} \\
\text { Reversed II - } \\
\text { Wright Medical } \\
\text { Group@ }\end{array}$ & No & 70 & Service & No & Negative \\
\hline 4 & Apr-15 & RSA & $\begin{array}{l}\text { Tornier Aequalis }^{\mathrm{TM}} \\
\text { Reversed II - } \\
\text { Wright Medical } \\
\text { Group@ }\end{array}$ & No & 43 & Service & $\begin{array}{l}\text { Yes, with skin } \\
\text { manifesta- } \\
\text { tion }\end{array}$ & Negative \\
\hline 5 & Dec-15 & RSA & $\begin{array}{l}\text { Bigliani/Flatow }{ }^{\circledR}- \\
\text { Zimmer Biomet } \odot\end{array}$ & No & 83 & Industry & No & Negative \\
\hline 6 & Sep-15 & RSA & $\begin{array}{l}\text { Tornier Aequalis }^{\mathrm{TM}} \\
\text { Reversed II - } \\
\text { Wright Medical } \\
\text { Group@ }\end{array}$ & No & 86 & Service & $\begin{array}{l}\text { Yes, without } \\
\text { skin mani- } \\
\text { festation }\end{array}$ & Negative \\
\hline 7 & Jan-16 & $\begin{array}{l}\text { Hemiarthro- } \\
\text { plasty }\end{array}$ & $\begin{array}{l}\text { Tornier Aequalis }{ }^{\mathrm{TM}} \\
\text { FX - Wright } \\
\text { Medical Group } \odot\end{array}$ & Yes & 52 & Service & $\begin{array}{l}\text { Yes, with skin } \\
\text { manifesta- } \\
\text { tion }\end{array}$ & Negative \\
\hline 8 & Mar-16 & $\begin{array}{l}\text { Hemiarthro- } \\
\text { plasty }\end{array}$ & $\begin{array}{l}\text { Tornier Aequalis }{ }^{\mathrm{TM}} \\
\text { FX - Wright } \\
\text { Medical Group } \odot\end{array}$ & Yes & 77 & Service & $\begin{array}{l}\text { Yes, with skin } \\
\text { manifesta- } \\
\text { tion }\end{array}$ & Negative \\
\hline 9 & May-16 & $\begin{array}{l}\text { Hemiarthro- } \\
\text { plasty }\end{array}$ & $\begin{array}{l}\text { Tornier Aequalis }{ }^{\mathrm{TM}} \\
\text { FX - Wright } \\
\text { Medical Group } \odot\end{array}$ & Yes & 81 & Industry & No & $\begin{array}{l}\text { Benzoyl Perox- } \\
\text { ide }(+)\end{array}$ \\
\hline 10 & Apr-15 & $\begin{array}{l}\text { Hemiarthro- } \\
\text { plasty }\end{array}$ & $\begin{array}{l}\text { Tornier Aequalis } \\
\text { FX - Wright } \\
\text { Medical Group } \odot\end{array}$ & No & 90 & Industry & No & Negative \\
\hline 11 & Sep-16 & RSA & $\begin{array}{l}\text { Tornier Aequalis }^{\mathrm{TM}} \\
\text { Reversed II - } \\
\text { Wright Medical } \\
\text { Group@ }\end{array}$ & Yes & 65 & Service & No & Negative \\
\hline 12 & Apr-16 & RSA & $\begin{array}{r}\text { Bigliani/Flatow }{ }^{\circledR}- \\
\text { Zimmer Biomet } \odot\end{array}$ & Yes & 69 & Service & $\begin{array}{l}\text { Yes, with skin } \\
\text { manifesta- } \\
\text { tion }\end{array}$ & Negative \\
\hline
\end{tabular}




\begin{tabular}{|c|c|c|c|c|c|c|c|c|}
\hline Id & Dos & Type of surgery & Type of Implant & $\begin{array}{l}\text { Cemented } \\
\text { Implant? }\end{array}$ & CMS & $\begin{array}{l}\text { Current/Pre- } \\
\text { vious sector } \\
\text { business }\end{array}$ & $\begin{array}{l}\text { Known Or } \\
\text { suspected } \\
\text { allergic symp- } \\
\text { toms }\end{array}$ & Patch test result \\
\hline 13 & Dec-15 & $\begin{array}{l}\text { Hemiarthro- } \\
\text { plasty }\end{array}$ & $\begin{array}{l}\text { Tornier Aequalis }{ }^{\mathrm{TM}} \\
\text { FX - Wright } \\
\text { Medical Group@ }\end{array}$ & Yes & 84 & Service & $\begin{array}{l}\text { Yes, without } \\
\text { skin mani- } \\
\text { festation }\end{array}$ & $\begin{array}{l}\text { Potassium } \\
\text { Dichromate } \\
(+)\end{array}$ \\
\hline 14 & Oct-16 & $\begin{array}{l}\text { Hemiarthro- } \\
\text { plasty }\end{array}$ & $\begin{array}{r}\text { Bigliani/Flatow }{ }^{\circledR}- \\
\text { Zimmer Biomet } \odot\end{array}$ & Yes & 67 & Service & No & Negative \\
\hline 15 & Nov-16 & $\begin{array}{l}\text { Hemiarthro- } \\
\text { plasty }\end{array}$ & $\begin{array}{l}\text { Tornier Aequalis }{ }^{\mathrm{TM}} \\
\text { FX - Wright } \\
\text { Medical Group@ }\end{array}$ & No & 79 & Service & $\begin{array}{l}\text { Yes, with skin } \\
\text { manifesta- } \\
\text { tion }\end{array}$ & Negative \\
\hline 16 & Feb-17 & RSA & $\begin{array}{l}\text { Bigliani/Flatow® - } \\
\text { Zimmer Biomet } \odot\end{array}$ & No & 51 & Industry & No & Negative \\
\hline 17 & Мay-16 & RSA & $\begin{array}{r}\text { Bigliani/Flatow® }- \\
\text { Zimmer Biomet } \odot ~\end{array}$ & No & 49 & Service & $\begin{array}{l}\text { Yes, with skin } \\
\text { manifesta- } \\
\text { tion }\end{array}$ & Negative \\
\hline 18 & Dec-15 & $\begin{array}{l}\text { Hemiarthro- } \\
\text { plasty }\end{array}$ & $\begin{array}{l}\text { Bigliani/Flatow }{ }^{\circledR}- \\
\text { Zimmer Biomet }\left({ }^{\circ}\right.\end{array}$ & No & 77 & Service & No & Negative \\
\hline 19 & Jul-17 & RSA & $\begin{array}{l}\text { Bigliani/Flatow® }{ }^{\circledR} \\
\text { Zimmer Biomet } \odot\end{array}$ & No & 79 & Service & $\begin{array}{l}\text { Yes, with skin } \\
\text { manifesta- } \\
\text { tion }\end{array}$ & Negative \\
\hline 20 & Apr-17 & RSA & $\begin{array}{l}\text { Tornier Aequalis }^{\mathrm{TM}} \\
\text { Reversed II - } \\
\text { Wright Medical } \\
\text { Group@ } \odot\end{array}$ & No & 89 & Service & $\begin{array}{l}\text { Yes, with skin } \\
\text { manifesta- } \\
\text { tion }\end{array}$ & Negative \\
\hline 21 & May-17 & RSA & $\begin{array}{l}\text { Tornier Aequalis }{ }^{\mathrm{TM}} \\
\text { Reversed II - } \\
\text { Wright Medical } \\
\text { Group@ }\end{array}$ & Yes & 85 & Service & No & Negative \\
\hline 22 & Feb-16 & RSA & $\begin{array}{l}\text { Tornier Aequalis }{ }^{\mathrm{TM}} \\
\text { Reversed II - } \\
\text { Wright Medical } \\
\text { Group } \bigodot\end{array}$ & No & 89 & Industry & $\begin{array}{l}\text { Yes, with skin } \\
\text { manifesta- } \\
\text { tion }\end{array}$ & Negative \\
\hline 23 & Apr-15 & RSA & $\begin{array}{l}\text { Tornier Aequalis }{ }^{\mathrm{TM}} \\
\text { Reversed II - } \\
\text { Wright Medical } \\
\text { Group@ }\end{array}$ & No & 68 & Service & No & Negative \\
\hline 24 & Aug-17 & RSA & $\begin{array}{l}\text { Tornier Aequalis }{ }^{\mathrm{TM}} \\
\text { Reversed II - } \\
\text { Wright Medical } \\
\text { Group@ }\end{array}$ & Yes & 62 & Service & $\begin{array}{l}\text { Yes, with skin } \\
\text { manifesta- } \\
\text { tion }\end{array}$ & $\begin{array}{l}\text { Nickel Sulfate } \\
(+++)\end{array}$ \\
\hline 25 & Jul-17 & $\begin{array}{l}\text { Hemiarthro- } \\
\text { plasty }\end{array}$ & $\begin{array}{l}\text { Bigliani/Flatow® - } \\
\text { Zimmer Biomet } @\end{array}$ & Yes & 45 & Service & No & Negative \\
\hline 26 & Jan-16 & RSA & $\begin{array}{l}\text { Tornier Aequalis }^{\mathrm{TM}} \\
\text { Reversed II - } \\
\text { Wright Medical } \\
\text { Group@ }\end{array}$ & Yes & 95 & Service & No & Negative \\
\hline 27 & Oct-17 & RSA & $\begin{array}{l}\text { Tornier Aequalis }^{\mathrm{TM}} \\
\text { Reversed II - } \\
\text { Wright Medical } \\
\text { Group@ } \odot\end{array}$ & Yes & 84 & Industry & No & Negative \\
\hline 28 & Oct-17 & RSA & $\begin{array}{l}\text { Bigliani/Flatow }{ }^{\circledR}- \\
\text { Zimmer Biomet } \odot\end{array}$ & Yes & 96 & Industry & $\begin{array}{l}\text { Yes, with skin } \\
\text { manifesta- } \\
\text { tion }\end{array}$ & $\begin{array}{l}\text { Nickel Sulfate } \\
(+)\end{array}$ \\
\hline 29 & May-16 & RSA & $\begin{array}{l}\text { Tornier Aequalis }{ }^{\mathrm{TM}} \\
\text { Reversed II - } \\
\text { Wright Medical } \\
\text { Group® }\end{array}$ & No & 63 & Service & No & Negative \\
\hline
\end{tabular}




\begin{tabular}{|c|c|c|c|c|c|c|c|c|}
\hline Id & Dos & Type of surgery & Type of Implant & $\begin{array}{l}\text { Cemented } \\
\text { Implant? }\end{array}$ & CMS & $\begin{array}{l}\text { Current/Pre- } \\
\text { vious sector } \\
\text { business }\end{array}$ & $\begin{array}{l}\text { Known Or } \\
\text { suspected } \\
\text { allergic symp- } \\
\text { toms }\end{array}$ & Patch test result \\
\hline 30 & Apr-16 & $\begin{array}{l}\text { Hemiarthro- } \\
\text { plasty }\end{array}$ & $\begin{array}{l}\text { Tornier Aequalis }^{\mathrm{TM}} \\
\text { FX - Wright } \\
\text { Medical Groupœ }\end{array}$ & No & 92 & Service & No & Negative \\
\hline 31 & Mar-17 & RSA & $\begin{array}{l}\text { Tornier Aequalis }{ }^{\mathrm{TM}} \\
\text { Reversed II - } \\
\text { Wright Medical } \\
\text { Group@ }\end{array}$ & Yes & 91 & Service & No & Negative \\
\hline 32 & Feb-15 & RSA & $\begin{array}{l}\text { Tornier Aequalis }{ }^{\mathrm{TM}} \\
\text { Reversed II - } \\
\text { Wright Medical } \\
\text { Group@ }\end{array}$ & No & 86 & Service & $\begin{array}{l}\text { Yes, without } \\
\text { skin mani- } \\
\text { festation }\end{array}$ & Negative \\
\hline 33 & May-15 & $\begin{array}{l}\text { Hemiarthro- } \\
\text { plasty }\end{array}$ & $\begin{array}{l}\text { Tornier Aequalis }^{\mathrm{TM}} \\
\text { FX - Wright } \\
\text { Medical Group@ }\end{array}$ & Yes & 85 & Service & $\begin{array}{l}\text { Yes, with skin } \\
\text { manifesta- } \\
\text { tion }\end{array}$ & Negative \\
\hline 34 & Dec-15 & $\begin{array}{l}\text { Hemiarthro- } \\
\text { plasty }\end{array}$ & $\begin{array}{l}\text { Tornier Aequalis }^{\mathrm{TM}} \\
\text { FX - Wright } \\
\text { Medical Groupœ }\end{array}$ & Yes & 74 & Service & No & Negative \\
\hline 35 & Nov-15 & $\begin{array}{l}\text { Hemiarthro- } \\
\text { plasty }\end{array}$ & $\begin{array}{l}\text { Tornier Aequalis }^{\mathrm{TM}} \\
\text { FX - Wright } \\
\text { Medical Group@ }\end{array}$ & Yes & 49 & Service & No & Negative \\
\hline 36 & Sep-15 & RSA & $\begin{array}{l}\text { Bigliani/Flatow }{ }^{\circledR}- \\
\text { Zimmer Biomet } \odot\end{array}$ & No & 77 & Service & No & Negative \\
\hline 37 & Jun-15 & $\begin{array}{l}\text { Hemiarthro- } \\
\text { plasty }\end{array}$ & $\begin{array}{l}\text { Tornier Aequalis }^{\mathrm{TM}} \\
\text { FX - Wright } \\
\text { Medical Groupœ }\end{array}$ & Yes & 71 & Service & No & Negative \\
\hline 38 & Oct-17 & $\begin{array}{l}\text { Hemiarthro- } \\
\text { plasty }\end{array}$ & $\begin{array}{r}\text { Bigliani/Flatow }{ }^{\circledR}- \\
\text { Zimmer Biomet } \odot\end{array}$ & No & 97 & Industry & $\begin{array}{l}\text { Yes, with skin } \\
\text { manifesta- } \\
\text { tion }\end{array}$ & Negative \\
\hline 39 & Aug-17 & RSA & $\begin{array}{l}\text { Tornier Aequalis }{ }^{\mathrm{TM}} \\
\text { Reversed II - } \\
\text { Wright Medical } \\
\text { Group@ }\end{array}$ & No & 90 & Service & No & Negative \\
\hline 40 & Jan-15 & RSA & $\begin{array}{c}\text { bigliani/Flatow }{ }^{\circledR}- \\
\text { Zimmer Biomet } \odot\end{array}$ & Yes & 88 & Service & No & Negative \\
\hline
\end{tabular}




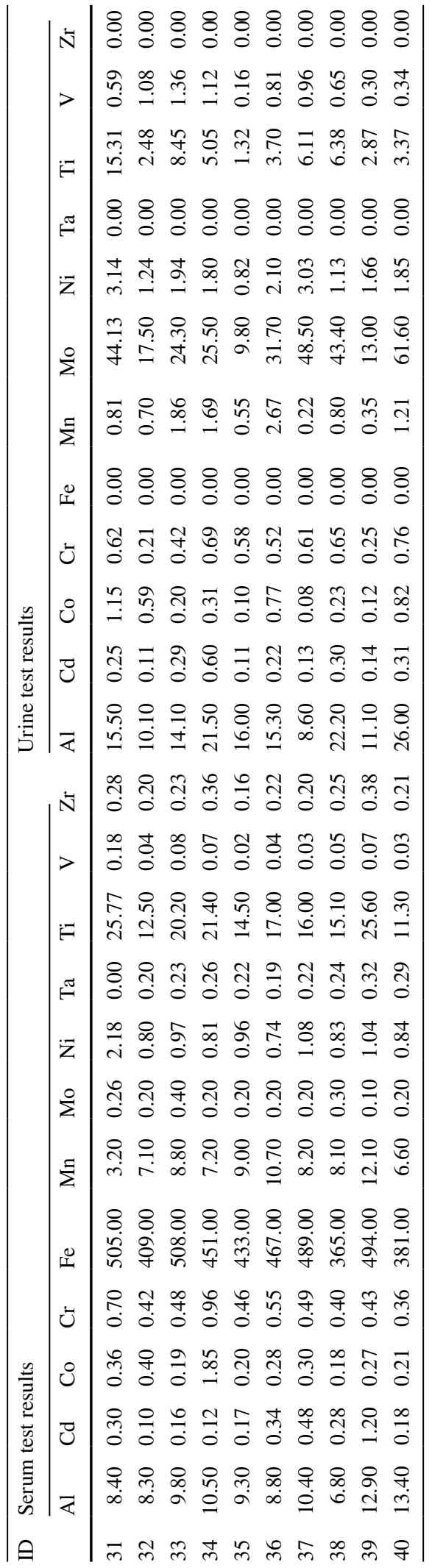

Funding Open access funding provided by Università degli Studi di Torino within the CRUI-CARE Agreement. This research did not receive any specific grant from funding agencies in the public, commercial, or not-for-profit sectors.

Availability of data and material Not applicable.

Code availability Not applicable.

\section{Declarations}

Conflicts of interest None of the authors, their immediate families, and any research foundation with which they are affiliated received any financial payments or other benefits from any commercial entity related to the subject of this article.

Institutional review board (IRB) Approval, or Ethical approval In light of the Italian law, we are not required to ask for Committee Approval for this type of study. However, each author certifies that his or her institution has approved the human protocol for this investigation and that all investigations were conducted in conformity with ethical principles of research. The study was performed in accordance with the ethical standards in the 1964 Declaration of Helsinki and was carried out in accordance with relevant regulations of the Italian National Health Care System. All Authors certify they have not signed any agreement with a commercial interest related to this study which would in any way limit publication of any data generated for the study or delay publication for any reason. This article does not contain any studies with animals performed by any of the authors.

Informed consent Informed consent was obtained from all individual participants included in the study.

Open Access This article is licensed under a Creative Commons Attribution 4.0 International License, which permits use, sharing, adaptation, distribution and reproduction in any medium or format, as long as you give appropriate credit to the original author(s) and the source, provide a link to the Creative Commons licence, and indicate if changes were made. The images or other third party material in this article are included in the article's Creative Commons licence, unless indicated otherwise in a credit line to the material. If material is not included in the article's Creative Commons licence and your intended use is not permitted by statutory regulation or exceeds the permitted use, you will need to obtain permission directly from the copyright holder. To view a copy of this licence, visit http://creativecommons.org/licenses/by/4.0/.

\section{References}

1. Alinaghi F, Bennike NH, Egeberg A et al (2019) Prevalence of contact allergy in the general population: A systematic review and meta-analysis. Contact Dermatitis 80:77-85. https://doi.org/ 10.1111/cod.13119

2. Hallab N, Wooley P (2014) Metal sensitivity: Is it possible to determine clinically? In: Jones L, Greenwald A, Haggard W (eds) Metal-on-Metal Bearings: A Clinical Practicum. Springer, New York, NY, pp 83-106

3. Wood MM, Warshaw EM (2015) Hypersensitivity reactions to titanium. Dermatitis 26:7-25. https://doi.org/10.1097/DER.00000 00000000091

4. Peat F, Coomber R, Rana A, Vince A (2018) Vanadium allergy following total knee arthroplasty. BMJ Case Rep 2018:bcr-2017222092 https://doi.org/10.1136/bcr-2017-222092 
5. Basko-Plluska JL, Thyssen JP, Schalock PC (2011) Cutaneous and systemic hypersensitivity reactions to metallic implants. Dermatitis 22:65-79. https://doi.org/10.2310/6620.2011.10055

6. Cadosch D, Chan E, Gautschi OP, Filgueira L (2009) Metal is not inert : Role of metal ions released by biocorrosion in aseptic loosening-Current concepts. J Biomed Mater Res Part A 91A:1252-1262. https://doi.org/10.1002/jbm.a.32625

7. Treudler R, Simon JC (2007) Benzoyl peroxide: is it a relevant bone cement allergen in patients with orthopaedic implants? Contact Dermatitis 57:177-180. https://doi.org/10.1111/j.1600-0536. 2007.01195.x

8. Barranco VP, Soloman H (1972) Eczematous dermatitis from nickel. JAMA J Am Med Assoc 220:1244. https://doi.org/10. 1001/jama.1972.03200090066016

9. Bircher A, Friederich NF, Seelig W, Scherer K (2012) Allergic complications from orthopaedic joint implants: the role of delayed hypersensitivity to benzoyl peroxide in bone cement. Contact Dermatitis 66:20-26. https://doi.org/10.1111/j.1600-0536.2011. 01996.x

10. Gao X, He R, Yan S, Wu L (2011) Dermatitis associated with chromium following total knee arthroplasty. J Arthroplasty 26:665.e13-665.e16. https://doi.org/10.1016/j.arth.2010.06.002

11. Symeonides PP, Paschaloglou C, Papageorgiou S (1973) An allergic reaction after internal fixation of a fracture using a Vitallium plate. J Allergy Clin Immunol 51:251-252. https://doi.org/10. 1016/0091-6749(73)90145-0

12. Kręcisz B, Kieć-Świerczyńska M, Bąkowicz-Mitura K (2006) Allergy to Metals as a Cause of Orthopedic Implant Failure. Int J Occup Med Environ Health 19:178-180. https://doi.org/10.2478/ v10001-006-0025-6

13. Stejskal V (2014) Metals as a common trigger of inflammation resulting in non-specific symptoms: diagnosis and treatment. Isr Med Assoc J 16:753-758

14. Eben R, Walk R, Summer B et al (2009) Implant allergy register-a first report. Orthopade 38:557-562. https://doi.org/10.1007/ s00132-009-1414-x

15. Dorr LD, Bloebaum R, Emmanual J, Meldrum R (1990) Histologic, biochemical, and ion analysis of tissue and fluids retrieved during total hip arthroplasty. Clin Orthop Relat Res. https://doi. org/10.1097/00003086-199012000-00010

16. Willert H-G, Buchhorn GH, Fayyazi A et al (2005) Metal-onmetal bearings and hypersensitivity in patients with artificial hip joints. J Bone Jt Surg 87:28-36. https://doi.org/10.2106/JBJS.A. 02039pp

17. Daniel J, Ziaee H, Pradhan C et al (2007) Blood and urine metal ion levels in young and active patients after Birmingham hip resurfacing arthroplasty: four-year results of a prospective longitudinal study. J Bone Joint Surg Br 89:169-173. https://doi.org/ 10.1302/0301-620X.89B2.18519

18. Urban RM, Jacobs JJ, Tomlinson MJ et al (2000) Dissemination of wear particles to the liver, spleen, and abdominal lymph nodes of patients with hip or knee replacement. J Bone Jt SurgeryAmerican 82:457-477. https://doi.org/10.2106/00004623-20000 4000-00002

19. Granchi D, Cenni E, Trisolino G et al (2006) Sensitivity to implant materials in patients undergoing total hip replacement. J Biomed Mater Res Part B Appl Biomater 77B:257-264. https://doi.org/ 10.1002/jbm.b.30445

20. Thyssen JP, Jakobsen SS, Engkilde K et al (2009) The association between metal allergy, total hip arthroplasty, and revision. Acta Orthop 80:646-652. https://doi.org/10.3109/17453670903487008

21. Bravo D, Wagner ER, Larson DR et al (2016) No increased risk of knee arthroplasty failure in patients with positive skin patch testing for metal hypersensitivity: A matched cohort study. J Arthroplasty 31:1717-1721. https://doi.org/10.1016/j.arth.2016.01.024
22. Reiner T, Bader N, Panzram B et al (2019) In vivo blood metal ion levels in patients after total shoulder arthroplasty. J Shoulder Elb Surg 28:539-546. https://doi.org/10.1016/j.jse.2018.08.027

23. Khan WS, Agarwal M, Malik AA et al (2008) Chromium, cobalt and titanium metallosis involving a Nottingham shoulder replacement. J Bone Joint Surg Br 90-B:502-505. https://doi.org/10. 1302/0301-620X.90B4.20302

24. Teeter MG, Carroll MJ, Walch G, Athwal GS (2016) Tribocorrosion in shoulder arthroplasty humeral component retrievals. J Shoulder Elb Surg 25:311-315. https://doi.org/10.1016/j.jse.2015. 07.004

25. Cusick MC, Hussey MM, Steen BM et al (2015) Glenosphere dissociation after reverse shoulder arthroplasty. J Shoulder Elb Surg 24:1061-1068. https://doi.org/10.1016/j.jse.2014.12.019

26. Eckert JA, Mueller U, Jaeger S et al (2016) Fretting and corrosion in modular shoulder arthroplasty: a retrieval analysis. Biomed Res Int 2016:1-7. https://doi.org/10.1155/2016/1695906

27. Koh J, Berger A, Benhaim P (2015) An overview of internal fixation implant metallurgy and galvanic corrosion effects. J Hand Surg Am 40:1703-1710.e4. https://doi.org/10.1016/j.jhsa.2015. 03.030

28. Sochol KM, Charen DA, Andelman SM, Parsons BO (2018) Cutaneous metallosis following reverse total shoulder arthroplasty. J Shoulder Elb Surg 27:e230-e233. https://doi.org/10.1016/j.jse. 2018.02.074

29. Mitchell JJ, Tahal DS, Katthagen JC et al (2017) Glenoid erosion leading to contact with retained metallic suture anchors. JBJS Case Connect 7:e24. https://doi.org/10.2106/JBJS.CC.16.00161

30. Lübbeke A, Rees JL, Barea $C$ et al (2017) International variation in shoulder arthroplasty. Acta Orthop 88:592-599. https://doi.org/ 10.1080/17453674.2017.1368884

31. Morwood MP, Garrigues GE (2015) Shoulder arthroplasty in the patient with metal hypersensitivity. J Shoulder Elb Surg 24:11561164. https://doi.org/10.1016/j.jse.2015.01.015

32. Ko J-WK, Nicholson TA, Hoffler CE et al (2017) Metal allergy as a cause of implant failure in shoulder arthroplasty. Orthopedics 40:e844-e848. https://doi.org/10.3928/01477447-20170719-01

33. Kennon JC, Lee J, Songy C et al (2020) The effect of patientreported metal allergies on the outcomes of shoulder arthroplasty. J Shoulder Elb Surg 29:296-301. https://doi.org/10.1016/j.jse. 2019.06.006

34. Constant CR, Murley AHG (1987) A clinical method of functional assessment of the shoulder. Clin Orthop Relat Res. https://doi.org/ 10.1097/00003086-198701000-00023

35. Società Italiana Valori di Riferimento (2011) Terza lista dei valori di riferimento per elementi, composti organici e loro metaboliti. http://www.sivr.it/documenti/sivr2011.pdf

36. Alimonti A, Bocca B, Mattei D, Pino A (2010) Biomonitoraggio della popolazione italiana per l'esposzione ai metalli: valori di riferimento 1990-2009

37. Stingeni L, Bianchi L, Hansel K et al (2019) Italian guidelines in patch testing - adapted from the european society of contact dermatitis (ESCD). G Ital di Dermatologia e Venereol 154:227-253. https://doi.org/10.23736/S0392-0488.19.06301-6

38. Ockenfels H-M, Uter W, Lessmann H et al (2009) Patch testing with benzoyl peroxide: reaction profile and interpretation of positive patch test reactions. Contact Dermatitis 61:209-216. https:// doi.org/10.1111/j.1600-0536.2009.01603.x

39. Khan M, Kuiper JH, Sieniawska C, Richardson JB (2016) Differences in concentration of metal debris in blood, serum, and plasma samples of patients with metal-on-metal hip resurfacing arthroplasty. J Orthop 13:450-454. https://doi.org/10.1016/j.jor. 2015.10.006

40. Savarino L, Granchi D, Ciapetti G et al (2003) Ion release in stable hip arthroplasties using metal-on-metal articulating surfaces: A 
comparison between short- and medium-term results. J Biomed Mater Res 66A:450-456. https://doi.org/10.1002/jbm.a.10595

41. Savarino L, Padovani G, Ferretti M et al (2008) Serum ion levels after ceramic-on-ceramic and metal-on-metal total hip arthroplasty: 8-year minimum follow-up. J Orthop Res 26:1569-1576. https://doi.org/10.1002/jor.20701

42. Grübl A, Weissinger M, Brodner W et al (2006) Serum aluminium and cobalt levels after ceramic-on-ceramic and metal-on-metal total hip replacement. J Bone Jt Surg - Ser B 88:1003-1005. https://doi.org/10.1302/0301-620X.88B8.17870

43. Savarino L, Tigani D, Greco M et al (2010) The potential role of metal ion release as a marker of loosening in patients with total knee replacement. J Bone Joint Surg Br 92-B:634-638. https:// doi.org/10.1302/0301-620X.92B5.23452

44. Klotz K, Weistenhöfer W, Neff F et al (2017) The health effects of aluminum exposure. Dtsch Aerzteblatt Online 114:653-659. https://doi.org/10.3238/arztebl.2017.0653

45. Milačič R, Murko S, Ščančar J (2009) Problems and progresses in speciation of $\mathrm{Al}$ in human serum: An overview. J Inorg Biochem 103:1504-1513. https://doi.org/10.1016/j.jinorgbio.2009.07.028

46. Back DL, Young DA, Shimmin AJ (2005) How do serum cobalt and chromium levels change after metal-on-metal hip resurfacing? Clin Orthop Relat Res. https://doi.org/10.1097/01.blo.00001 $66901.84323 .5 \mathrm{~d}$
47. Vassiliou K, Elfick DAP, Scholes SC, Unsworth A (2006) The effect of 'running-in' on the tribology and surface morphology of metal-on-metal Birmingham hip resurfacing device in simulator studies. Proc Inst Mech Eng Part H J Eng Med 220:269-277. https://doi.org/10.1243/09544119JEIM63

48. Carpenter S, Pinkas D, Newton MD et al (2015) Wear rates of retentive versus nonretentive reverse total shoulder arthroplasty liners in an in vitro wear simulation. J Shoulder Elb Surg 24:1372-1379. https://doi.org/10.1016/j.jse.2015.02.016

49. Richards LJ, Streifel A, Rodrigues JM (2019) Utility of patch testing and lymphocyte transformation testing in the evaluation of metal allergy in patients with orthopedic implants. Cureus 11:e5761. https://doi.org/10.7759/cureus.5761

50. Carossino AM, Carulli C, Ciuffi S et al (2016) Hypersensitivity reactions to metal implants: laboratory options. BMC Musculoskelet Disord 17:486. https://doi.org/10.1186/s12891-016-1342-y

Publisher's Note Springer Nature remains neutral with regard to jurisdictional claims in published maps and institutional affiliations. 